\title{
Faktor-faktor Keruangan yang Berpengaruh terhadap Kriminalitas di Kota Surabaya
}

\author{
Retno Yuniar Azarine dan Putu Rudy Satiawan \\ Departemen Perencanaan Wilayah dan Kota, Fakultas Arsitektur, Desain dan Perencanaan \\ Institut Teknologi Sepuluh Nopember Surabaya \\ e-mail: puturudy@yahoo.com
}

\begin{abstract}
Abstrak-Daya tarik Kota Surabaya sebagai kota terbesar kedua di Indonesia meningkatkan persaingan diantara masyarakatnya untuk mendapat kehidupan yang lebih baik. Persaingan inilah yang menyebabkan angka kriminalitas di Kota Surabaya menjadi tinggi. Kejahatan jalanan merupakan kejahatan yang berada pada ruang publik dan dapat terjadi pada seorang. Seorang pelaku kejahatan tentunya tidak melakukan kejahatan di suatu tempat tidak berdasarkan pertimbangan. Sehingga lokasi kejahatan tersebut dapat dipelajari. Ruang-ruang terisolasi, sepi, gelap, tidak terdapat banyak orang dianggap lebih rawan akan kejahatan. Disamping itu lingkungan dengan masyarakat kurang mengenal satu sama lain, lingkungan dengan kepadatan tinggi. lingkungan yang kurang terawat, dan kurang rapi dapat memicu terjadinya kejahatan.

Wawancara terhadap responden mengenai persepsi mereka terhadap sebuah ruang kriminalitas. Melalui metode content analysis dari hasil wawancara, diinterpretasikan pendapat responden mengenai faktor ruang yang memicu kriminalitas. Melalui content analysis tersebut pula dapat diketahui ruangruang yang memicu kejahatan di luar adanya teori atau stereotip masyarakat.

Dari penelitian ini didapatkan persepsi-persepsi masingmasing responden terhadap ruang rawan kejahatan. Sehingga didapatakan variabel keruangan yang memicu kriminalitas menurut berbagai sudut pandang.
\end{abstract}

Kata Kunci- ruang rawan, pemicu kejahatan, kejahatan jalanan, keruangan, content analysis.

\section{PENDAHULUAN}

$\mathrm{S}$ URABAYA sebagai ibukota Propinsi Jawa Timur memiliki catatan kejadian kriminal, seperti dalam Operasi Pekat Semeru 2017 yang dilakukan Polrestabes Surabaya beserta Polsek jajaran. Hasilnya, operasi yang dilakukan sejak 23 Mei sampai 3 Juni 2017 ini didominasi hasil ungkap kejahatan (street crime) di Kota Surabaya. Adapun rinciannya, jumlah ungkap kasus kejahatan jalanan sebanyak 75 perkara. Dengan klasifikasi, 27 kasus pencurian dengan pemberatan (Curat), 24 kasus pencurian dengan kekerasan (Curas), 24 kasus pencurian kendaraan bermotor (Curanmor), dan 10 kasus pencurian biasa. Sedangkan jumlah tersangka yang berhasil diamankan sebanyak 73 orang. Diperingkat selanjutnya ditempati perkara prostitusi. Kemudian perkara premanisme sebanyak 16 kasus, dengan tersangka sebanyak 28 orang. Dan peringkat terakhir adalah perkara perjudian.

Selain tersangka dari berbagai tindak kejahatan, barang bukti yang diamankan dari Operasi Pekat Semeru 2017 ini diantaranya, 33 unit motor, 4 unit mobil, 32 kunci T, 3 bilah sajam, I unit airgun FN Makarov, 10 butir peluru, uang tunai sekitar Rp 14.436.000, kartu remi, 132 keping dvd porno, rekaman cctv. Selama November, sebanyak 137 pelaku kejahatan di Surabaya dibekuk. Mereka bertanggung jawab atas 128 kasus yang terjadi. Kasus yang menonjol masihlah kasus kejahatan jalanan atau 3C (curat, curas, curanmor). Kasus pencurian dengan pemberatan (curat) mendominasi dengan 62 kasus dan 55 tersangka. Berikutnya adalah kasus curanmor dengan jumlah 22 kasus dan 22 tersangka. Sementara itu, kasus pencurian dengan kekerasan (curas) juga banyak dengan jumlah 19 kasus dan 19 tersangka. Sedangkan dua kasus lain yang diungkap adalah penipuan dengan 5 kasus dan 12 tersangka, serta kasus penadahan dengan 8 kasus dan 8 tersangka.

Pendekatan utama dalam mencegah kriminalitas, yaitu : Dispositional - mengurangi motivasi individu untuk melakukan kejahatan melalui pendidikan moral, sanksi, dan pembangunan sosial ekonomi. Pendekatan kedua adalah Situational - membuat pelaku kriminal tidak dapat melakukan kejahatannya, dengan membuat situasi tempat yang tidak memungkinkan bagi mereka untuk berbuat jahat. Melalui pendekatan situasional dapat diidentifikasi kondisi lingkungan fisik dan sosial yang memberikan peluang untuk terjadinya kriminalitas, dan memodifikasi kondisi tersebut untuk mengurangi peluang kejahatan tersebut. Sehingga penelitian ini bertujuan untuk mencari faktor apakah yang berpengaruh terhadap sebuah kejahatan.

\section{URAIAN PENELITIAN}

\section{A. Pendekatan Penelitian}

Penelitian tentang penentuan karakteristik ruang kriminalitas pada Kota Surabaya ini menggunakan metode yang berdasarkan pada pendekatan studi rasionalistik. Metode pendekatan studi rasionalistik menekankan pada pemahaman secara holistik yang dilakukan melalui konsepsualisasi teoritik dan studi literatur sebagai tolok ukur pendekatan uji, hasil analisis, dan pembahasan suatu masalah penelitian untuk menarik kesimpulan dan pemaknaan. Pendekatan rasionalistik umumnya digunakan dalam penyusunan kerangka konsep teoritik, dimana semua ilmu berasal dari pemaknaan intelektual yang dibangun atas kemampuan berargumentasi secara logika yang ditekankan pada pemaknaan sensual, etik, dan logis dengan syarat empiris yang relevan. 


\section{B. Variabel dan Dimensi}

Dimensi dalam penelitian merupakan kemungkinankemungkinan definisi dari sudut pandang responden.

Tabel 1.

Variabel dan Dimensi

\begin{tabular}{|c|c|}
\hline Variabel & Dimensi \\
\hline \multirow[t]{2}{*}{ Terisolasi } & $\begin{array}{l}\text { Ruang publik tertutup dalam } \\
\text { gedung }\end{array}$ \\
\hline & $\begin{array}{l}\text { Ruang buntu tanpa jalan } \\
\text { alternatif }\end{array}$ \\
\hline Tingkat Keramaian & $\begin{array}{l}\text { Lokasi berada jauh dari } \\
\text { keramaian }\end{array}$ \\
\hline \multirow[t]{3}{*}{ Akses } & Hak untuk memasuki \\
\hline & Jalan melarikan diri \\
\hline & Jalan menyelamatkan diri \\
\hline Mengenali Ruang & $\begin{array}{l}\text { Mengenali ruang dalam state of } \\
\text { mind masing masing individu }\end{array}$ \\
\hline \multirow[t]{2}{*}{ Pilihan Rute } & Pilihan rute melarikan diri \\
\hline & Pllihan Rute menyelamatkan diri \\
\hline \multirow[t]{2}{*}{ Interaksi } & Ikatan Sosial yang kuat \\
\hline & Keterlibatan dalam mencagah \\
\hline \multirow[t]{2}{*}{ Keseimbangan Kegiatan } & $\begin{array}{l}\text { Keseimbangan usaha aktif dan } \\
\text { pasif }\end{array}$ \\
\hline & Keseimbangan antar kegiatan \\
\hline Terawat & $\begin{array}{l}\text { Terpelihara, terjaga, dan layak } \\
\text { huni }\end{array}$ \\
\hline Rapi & Teratur, bersih, tertib \\
\hline Public Space & $\begin{array}{l}\text { Tempat umum dengan banyak } \\
\text { orang }\end{array}$ \\
\hline \multirow[t]{2}{*}{$\begin{array}{l}\text { Keterjangkauan } \\
\text { penglihatan }\end{array}$} & 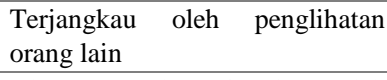 \\
\hline & $\begin{array}{l}\text { Akses masuk terjangkau oleh } \\
\text { penglihatan }\end{array}$ \\
\hline \multirow[t]{2}{*}{ Keraparan } & Kerapatan bangunan \\
\hline & Kerapatan tanaman \\
\hline \multirow[t]{2}{*}{ Sudut pandang penglihatan } & Terhalang oleh bangunan \\
\hline & Terhalang oleh tanaman \\
\hline Rasa Memiliki Ruang & Menguasai ruang \\
\hline \multirow[t]{2}{*}{ Pencahayaan } & Cahaya lampu \\
\hline & Siang hari \\
\hline
\end{tabular}

\section{Sampel}

Metode sampling yang digunakan penelitian ini adalah teknik Purposive Sampling. Purposive sampling adalah pengambilan sampel dilakukan hanya atas dasar pertimbangan penelitinya saja yang menganggap unsur-unsur yang dikehendaki telah ada dalam anggota sampel yang diambil (Nasution, 2003) ${ }^{[13]}$. Purposive sampling disebut juga Judgment Sampling. Satuan sampling dipilih berdasarkan pertimbangan tertentu dengan tujuan untuk memperoleh satuan sampling yang memiliki karakteristik yang dikehendaki (Setiawan, 2005) ${ }^{[25]}$.

Adapun sampling dalam penelitian ini adalah 1 orang pelaku kejahatan jalanan, 1 orang pihak kepolisian, 1 orang korban kejahatan jalanan, 1 orang sosiolog, dan 1 orang ahli hukum.

Adapun kriteria dalam penentuan sampel penelitian sebagai berikut:

a. Terdapat satu orang mantan pelaku kejahatan 3C di Kota Surabaya.

Pelaku dibutuhkan untuk menjadi responden dikarenakan pelaku merupakan individu yang paling mengerti tentang motif pemilihan ruang terjadinya kriminalitas.

1. Sering melakukan kejahatan di tempat yang sama

2. Mengenal dan mengetahui pola kejadian kriminalitas pada wilayah aksinya

3. Memahami kondisi eksisting wilayah aksinya

b. Terdapat satu orang sosiolog

Sosiolog dibutuhkan menjadi responden dikarenakan perilaku kriminal itu sendiri menjadi salah satu bidang yang dipelajari di keilmuan sosiologi. Sosiologi kriminal sendiri menjawab sampai dimana letak sebab-sebab kejahatan dalam masyarakat termasuk didalamnya kesan sebuah ruang.

1. Memiliki bidang keilmuan sosiologi

2. Memiliki bidang keahlian khusus atau mempelajari kriminologi

3. Memahami kondisi eksisting wilayah penelitian

c. Terdapat satu orang ahli hukum

Ahli hukum diperlukan untuk menjadi responden dikarenakan memiliki latar belakang keilmuan yang mempelajari filosofi keruangan dibalik pelanggaran hukum/pasal.

1. Memiliki bidang keilmuan hukum

2. Memiliki bidang keahlian khusus atau mempelajari property crime

3. Memahami kondisi eksisting wilayah penelitian

d. Terdapat satu orang kepolisian

Kepolisian dibutuhkan menjadi responden karena pihak yang berhubungan langsung antara pelaku dengan korban kejahatan.

1. Bekerja pada unit Reserse Kriminal Kepolisian

2.Pernah menyelidiki atau menangani kasus penjambretan, pencopetan, atau pencurian kendaraan bermotor

3. Memahami kondisi eksisting wilayah penelitian

e. Terdapat satu orang masyarakat yang pernah menjadi korban kejahatan 3C.

Korban kejahatan 3C dibutuhkan karena pihak yang mengalami secara langsung kejahatan tersebut. Dan selaku pihak yang menjadi incaran dalam posisinya sebagai masyarakat untuk dicari persepsinya tentang ruang yang rawan akan kriminalitas.

1.Pernah mengalami minimal satu kali kejahatan penjambretan/pencopetan/pencurian kedaraan bermotor.

2. Bertempat tinggal dalam lingkup wilayah penelitian.

3. Memahami kondisi eksisting wilayah penelitian.

\section{HASIL DAN DISKUSI}

Faktor yang berengaruh terhadap kriminalitas dapat berbeda-beda pada setiap orang. Tergantung pada persepsi masing-masing individu terhadap kriminailtas itu sendiri. Persepsi terhadap faktor yang berpengaruh terhadap adanya kriminalitas juga dapat bergantung pada background individu tersebut. Berikut faktor-faktor yang berpengaruh terhadap 
kriminaitas menurut beberapa sudut pandang :

1. Faktor yang berpengaruh terhadap kriminalitas menurut sudut pandang pelaku adalah :

- Faktor Tidak Terisolasi

- Faktor Pola Akses

- Faktor Mengenali/Menguasai Medan

- Faktor Mengenali Korban/Masyarakat

- Faktor Adanya Pilihan Rute

- Faktor Kurangnya Interaksi

- Faktor Kurangnya Kontrol Sosial

- Faktor Keberadaan Tempat Umum

- Faktor Kurangnya Keterjangkauan Penglihatan

- Faktor Penguasaan/Kepemilikan Ruang oleh Pelaku

- Faktor Ruang Terang

- Faktor Naluri Pelaku

2. Faktor yang berpengaruh terhadap kriminalitas menurut sudut pandang kepolisian adalah :

- Faktor Tidak Terisolasi

- Faktor Ruang Sepi

- Faktor Kurangnya Pengenalan Ruang oleh Masyarakat

- Faktor Adanya Pilihan Rute

- Faktor Kurangnya Kontrol Sosial

- Faktor Jenis Kegiatan

- Faktor Ruang Kurang Terawat

- Faktor Keberadaan Tempat Umum

- Faktor Kurangnya Keterjangkauan Penglihatan

- Faktor Kurangnya Sudut Pandang Penglihatan

- Faktor Kurangnya Penguasaan Ruang oleh Masyarakat

- Faktor Daytime

3. Faktor yang berpengaruh terhadap kriminalitas menurut sudut pandang sosiolog adalah :

- Faktor Terisolasi

- Faktor Adanya Akses

- Faktor Mengenali Korban/Masyarakat

- Faktor Mengenali/Menguasai Medan

- Faktor Mengenali Korban/Masyarakat

- Faktor Kurangnya Pengenalan Ruang oleh Masyarakat

- Faktor Adanya Pilihan Rute

- Faktor Kurangnya Kontrol Sosial

- Faktor Ruang Kurang Terawat

- Faktor Ruang Kurang Rapi

- Faktor Ruang Rapi

- Faktor Keberadaan Tempat Umum

- Faktor Ruang Privat

- Faktor Tidak Adanya CCTV

- Faktor Kurangnya Keterjangkauan Penglihatan

- Faktor Kurangnya Kerapatan

- Faktor Kurangnya Sudut Pandang Penglihatan

- Faktor Penguasaan Ruang oleh Pelaku

- Faktor Kurangnya Penguasaan Ruang oleh Masyarakat

4. Faktor yang berpengaruh terhadap kriminalitas menurut sudut pandang korban kejahatan $3 \mathrm{C}$ adalah:

- Faktor Terisolasi
- Faktor Ruang Ramai

- Faktor Ruang Sepi

- Faktor Pola Akses

- Faktor Kurangnya Pengenalan Ruang oleh Masyarakat

- Faktor Kurangnya Iteraksi

- Faktor Kurangnya Kontrol Sosial

- Faktor Keseimbangan Kegiatan

- Faktor Ruang Kurang Terawat

- Faktor Kurangnya Keterjangkauan Penglihatan

- Faktor Kurangnya Kerapatan

- Faktor Kurangnya Penguasaan Ruang oleh Masyarakat

- Faktor Ruang Gelap

5. Faktor yang berpengaruh terhadap kriminalitas menurut sudut pandang ahli hukum adalah :

- Faktor Terisolasi

- Faktor Ruang Sepi

- Faktor Adanya Akses

- Faktor Mengenali/Menguasai Medan

- Faktor Mengenali Korban/Masyarakat

- Faktor Kurangnya Pengenalan Ruang oleh Masyarakat

- Faktor Adanya Pilihan Rute

- Faktor Kurangnya Kontrol Sosial

- Faktor Keberadaan Tempat Umum

- Faktor Tidak Adanya CCTV

- Faktor Kurangnya Keterjangkauan Penglihatan

- Faktor Kuranganya Sudut Pandang Penglihatan

- Faktor Kurangnya Penguasaan Ruang oleh Masyarakat

Melalui wawancara dengan responden didapatkan bahwa teori-teori mengenai pencegahan dan penyebab kejahatan melalui keruangan tidak sepenuhnya dibenarkan dan diaplikasikan oleh pelaku kejahatan tersebut. Bahkan diantaranya bertolak belakang. Pelaku kejahatan memiliki pemahaman sendiri mengenai ruang-ruang yang memberinya potensi untuk melakukan kejahatan. Sementara teori-teori yang selama ini berkembang telah membentuk persepsi masyarakat dari berbagai kalangan, bahkan pihak yang ebrwajib sekalipun mengenai ruang yang rawan kejahatan. Sementara teori-teori tersebut kurang relevan untuk merepresentasikan criminal mind dari pelaku, sehingga pencegahan yang dilakukan sebagai jawaban atas teori penyebab kejahatan jalanan juga kurang tepat.

\section{A. Terisolasi}

Terdapat pertentangan antara pendapat beberapa responden, dan teori Defensible Space. Korban/masyarakat, sosiolog, dan ahli hukum ruang yang aman adalah ruang yang tidak terisolasi sesuai dengan teori pada Defensible Space, padahal menurut pelaku dan data kriminal kepolisian, kejahatan cenderung terjadi di ruang yang tidak terisolasi.

\section{B. Tingkat Keramaian}

Terdapat pertentangan antara pendapat beberapa responden, dan teori Defensible Space. Korban/masyarakat, 
sosiolog, kepolisian, dan ahli hukum ruang yang aman adalah ruang yang ramai sesuai dengan teori pada Defensible Space, padahal menurut pelaku kejahatan cenderung terjadi di ruang yang tidak terisolasi.

\section{Akses}

Responden setuju kemudahan akses memicu terjadinya kriminalitas. Akses yang mempermudah pelaku dalam serangkaian proses kejahatan adalah akses yang tidak membutuhkan waktu lama untuk melakukan obervasi, seperti akses dengan pola ring road dan $u$-turn.

\section{Mengenali Ruang}

Pengenalan ruang jika dilakukan oleh pelaku maka akan meningkatkan resiko terjadinya kriminalitas, sementara ketika pengenalan ruang dilakukan oleh masyarakat maka dapat menjadi pencegahan terjadinya kejahatan.

\section{E. Pilihan Rute}

Masyarakat cenderung melewati rute yang sama setiap harinya. Alasan pemilihan rute tersebut adalah tingkat keramaian dari rute tersebut. Semakin ramai maka akan semakin memberikan persepsi aman pada masyarakat. Sementara pilihan rute dimanfaatkan oleh pelaku karena kejahatan yang dilakukan saat ini mayoritas merupakan kejahatan sindikat (membutuhkan arah pelarian yang berbeda-beda).

\section{F. Interaksi}

Seluruh reponden sepakat bahwa ruang dengan interaksi masyarakat yang kuat akan mengurangi resiko terjadinya kejahatan di ruang tersebut.

\section{G. Keseimbangan Kegiatan}

Pelaku tidak merasa mempolakan potensi-potensi seseorang untuk menjadi calon korban berdasarkan jenis kegiatannya. Akan tetapi kecenderungannya, pelaku melakukan observasi dan eksekusi di sekitar perdagangan dan jasa. Sementara masyarakat, sosiolog, dan ahli hukum berpendapat bahwa yang mempengaruhi terjadinya kejahatan bukannlah jenis kegiatannya, melainkan sistem penjagaannya.

\section{H. Terawat}

Keterawatan dan kerapian lebih cenderung didefinisikan tidak mempengaruhi terjadinya kriminalitas itu sendiri. Kecuali jika keterawatan atu kerapian didefinisikana sebagai ruang dengan penjagaan yang baik dan interaksi masyarakat yang kuat.

\section{Rapi}

Keterawatan dan kerapian lebih cenderung didefinisikan tidak mempengaruhi terjadinya kriminalitas itu sendiri. Kecuali jika keterawatan atu kerapian didefinisikan sebagai ruang dengan penjagaan yang baik dan interaksi masyarakat yang kuat.

\section{J. Public Space}

Masyarakat lebih merasa aman saat berada di ruang publik karena merasa adanya banyak orang yang memungkinkan untuk mengawasi. Padahal menurut pelaku, ahli hukum, dan data rekam kejadian, kriminalitas cenderung di ruang publik. Hal ini bertentangan dengan teori Crime Prevention through Environment Design.

\section{K. Keterjangkauan oleh Penglihatan}

Keterjangkauan penglihatan, kerapatan, dan sudut pandang penglihatan lebih berperan memberikan perepsi aman bagi masyarakat, meskipun pelaku tidak mempertimbangkan hal tersebut.

\section{Kerapatan}

Keterjangkauan penglihatan, kerapatan, dan sudut pandang penglihatan lebih berperan memberikan perepsi aman bagi masyarakat, meskipun pelaku tidak mempertimbangkan hal tersebut.

\section{Sudut Pandang Penglihatan}

Keterjangkauan penglihatan, kerapatan, dan sudut pandang penglihatan lebih berperan memberikan perepsi aman bagi masyarakat, meskipun pelaku tidak mempertimbangkan hal tersebut.

\section{N. Rasa Memiliki Ruang}

Rasa memiliki ruang jika dimiliki oleh masyarakat maka dapat mengurangi resiko terjadinya kejahatan. Jika rasa memiliki ruang dimiliki oleh pelaku maka akan meningkatkan resiko kejahatan. Pelaku tidak merasa memiliki ruang yang dikuasai/dimiliki, akan tetapi perilakunya membuktikan bahwa adanya bentuk-bentuk mempertahankan ruang ketika adanya orang asing yang masuk.

\section{O. Pencahayaan}

Masyarakat merasa ruang yang lebih aman adalah ruang yang terang, sesuai dengan teori Defensible Space. Akan tetapi hal ini bertentangan dengan apa yang dianut oleh pelaku, bahwa pelaku juga cenderung untuk melakukan aksinya di ruang yang terang, Karena pertimbangan tidak adanya masyarakat/calon korban yang berkegiatan di ruang yang gelap.

\section{KESIMPULAN/RINGKASAN}

Berdasarkan penelitian faktor keruangan yang memicu kriminalitas berdasarkan lima sudut pandang, didapatkan hasil yaitu menurut pelaku kejahatan 3C faktor yang memicu adalah tidak terisolasi; pola akses; mengenali/menguasai medan; mengenali korban/masyarakat; adanya pilihan rute; kurangnya interaksi; kurangnya kontrol sosial; keberadaan tempat umum; kurangnya keterjangkauan penglihatan; penguasaan/kepemilikan ruang oleh pelaku; ruang terang; faktor naluri pelaku.

Sementara menurut kepolisian faktor keruangan yang memicu kriminalitas adalah tidak terisolasi; ruang sepi; kurangnya pengenalan ruang oleh masyarakat; adanya pilihan rute; kurangnya kontrol sosial; jenis kegiatan; ruang kurang terawatt; keberadaan tempat umum; kurangnya keterjangkauan penglihatan; kurangnya sudut pandang penglihatan; kurangnya penguasaan ruang oleh masyarakat; daytime. 
Menurut sosiolog faktor keruangan yang memicu kriminalitas adalah terisolasi; adanya akses; mengenali korban/masyarakat; mengenali/menguasai medan; mengenali korban/masyarakat; kurangnya pengenalan ruang oleh masyarakat; adanya pilihan rute; kurangnya kontrol sosial; ruang kurang terawatt; ruang kurang rapi; ruang rapi; keberadaan tempat umum; ruang privat; tidak adanya CCTV; kurangnya keterjangkauan penglihatan; kurangnya kerapatan; kurangnya sudut pandang penglihatan; penguasaan ruang oleh pelaku; kurangnya penguasaan ruang oleh masyarakat.

Menurut korban kejahatan 3C faktor keruangan yang memicu kriminalitas adalah terisolasi; ruang ramai; ruang sepi; pola akses; kurangnya pengenalan ruang oleh masyarakat kurangnya interaksi; kurangnya kontrol sosial; keseimbangan kegiatan; ruang kurang terawatt; kurangnya keterjangkauan penglihatan; kurangnya kerapatan; kurangnya penguasaan ruang oleh masyarakat; ruang gelap.

Menurut ahli hukum faktor keruangan yang memicu kriminalitas adalah terisolasi; ruang sepi; adanya akses; mengenali/menguasai medan; mengenali korban/masyarakat; kurangnya pengenalan ruang oleh masyarakat; adanya pilihan rute; kurangnya kontrol sosial; eberadaan tempat umum; tidak adanya CCTV; kurangnya keterjangkauan penglihatan; kuranganya sudut pandang penglihatan; kurangnya penguasaan ruang oleh masyarakat.

Secara keseluruhan terdapat beberapa faktor yang sesuai dengan teori dan terdapat beberapa faktor yang bertentangan dengan teori seperti terisolasi, tingkat keramaian, public space, dan pencahayaan.

\section{DAFTAR PUSTAKA}

[1] Aldrin, A., Marzbali, M. H., Razak, N. A., \& Tilaki, M. J. M. (2011). A Review of the Effetiveness of Crime Prevention by Design Approaches toward Sustainable Development. Journal of Sustainable Development, Volume 4, No 1

[2] Aldrin, A., Marzbali, M. H., Aldrin, A., Bahauddin, A., Marzbali, M. H., \& Tilaki, M. J. M. (2012). The Relationship between Territorial Functioning and Victimisation: A Comparative Study of High and Low Crime Rate Estate. Procedia - Social and Behavioral Sciences 50 (2012) 899-908

[3] Aman. Metodogi Penelitian Kualitatif

[4] Andresen, M. A. (2014). Environmental Criminology: Evolution, Theory, and Practice.

[5] Bahaluddin, A., Hassan, K., Sakip, S. R. M. (2016). The Effect of Mural on Personal Crime and Fear of Crime. Procedia - Social and Behavioral Sciences 234 (2016) 407-415
[6] Cozens, P. M., Saville, G., Hillier, D. (2005). Property Management. Crime Prevention Through Environment Design (CPTED) : a review and moders bibliography, 328-344.

[7] Dewi, N. K, Sunarsih, Y., Agustina, G., Nurlaily, Z., Dewi, R. A. 2010. Populasi dan Sampel. Universitas Negeri Yogyakarta.

[8] Hussein, M. Z. S. M., Ismail, H. N., Sham, R. (2013). A Review of Social Structure, Crime Quality Of Life as Women Travelers in Malaysian Cities. Procedia - Social and Behavioral Sciences 101 (2013) 307-317

[9] Jones and Bartlett Publisher. Environmental Criminology. Chapter 3.

[10] Kamalipour, H., Faizi, M., \& Memarian, G. (2014). Safe Place by Design: Urban Crime in Relation to Spatiality and Sociality. Current Urban Studies, 2, 152-162.

[11] Kamalipour, H., Memarian, G. and Faizi, M. (2014) Urban Crime and Pattern Conceptions: Departuring from Spatiality. Open Journal of Social Sciences, 2, 441-450.

[12] Mazerolle, L., Wortley, R. (2008). Environmental Criminology and Crime Analysis.

[13] Nasution, R.. 2003. Teknik Sampling. Universitas Sumatera Utara

[14] Nayan, N. M., Rahman, N. A., Sakip, S. R. M. (2016). Do They Feel Fear Without Fence?. Procedia - Social and Behavioral Sciences 222 (2016) 738-746

[15] Tucunan, K. (2011). Thesis Pola Ruang Kriminalitas Kota Studi Kasus Kota Surabaya. Universitas Gadjah Mada.

[16] Pratiwi, N. N. (2014). Skripsi Kajian Sosiologis Bentuk-Bentuk Kriminalitas di Angkutan Umum. Universitas Lampung.

[17] Portland Government. (2015). Crime Prevention Through Environmental Design. Crime Prevention Program. City of Portland.

[18] Queensland Government. (2007). Crime Prevention Through Environmental Design: Guidelines for Queensland. Part A Essential Features of Safer Places. The State of Queensland.

[19] Ruansyah, R., (2016). Tugas Akhir Pengaruh Ketersediaan Taman terhadap Tingkat Kriminalitas di Kota Surabaya. Institut Teknologi Sepuluh Nopember.

[20] Rusman, L. (2014). Skripsi Tinjauan Kriminologis terhadap Kejahatan Perjudian di Kota Bau-Bau. Universitas Hassanudin.

[21] Setiawan, N. 2005. DIklat Metodologi Penelitian Sosial : Teknik Sampling. Universitas Padjajaran

[22] Setyowati, T. W., Naurina, V., Wulan A, D., Anggraini, A. W., Merdekawati, A., Karni. 2010. Anailis Data. Universitas Negeri Yogyakarta.

[23] Singapore Government. (2003). Crime Prevention Through Environmental Design Guidebook. National Crime Prevention Council of Singapore.

[24] Suryana. 2010. Buku Ajar Perkuliahan Metodologi Penelitian: Model Praktis Kuantitatif dan Kualitatif. Universitas Pendidikan Indonesia.

[25] Sutisna, Ade. 2008. Tinjauan Ringkas Etnografi sebagai Metode Penelitian Kualitatif, dalam http://file.upi.edu/Direktori/FPBS/JUR._PEND._BAHASA_DAERAH $/ 197607$

312001121ADE_SUTISNA/Tinjauan_Ringkas_Etnografi_Sebagai_Metode_Pene litian_Kualita.pdf. Diunduh pada 17 Mei 2018.

[26] United States Government. (1996). Creating Defensible Space. United States Department of Housing and Urban Development. Office of Policy Development and Research. 